\title{
Play and Purpose: The Relationship Between Patolli and Graffiti at Xunantunich, Belize
}

Rosamund Fitzmaurice ${ }^{1, \star}$, Tia B Watkins ${ }^{1}$ and Jaime J Awe ${ }^{2}$

How to cite: Fitzmaurice, R, Watkins T B and Awe, J J. Play and Purpose: The Relationship Between Patolli and Graffiti at Xunantunich, Belize. Papers from the Institute of Archaeology, 2021, 30(1): pp. 60-92. DOI:

https://doi.org/10.14324/111.444.2041-9015.1286

Published: $15 / 11 / 2021$

\section{Peer Review:}

This article has been peer reviewed through the journal's standard double-blind review.

\section{Copyright:}

(C) 2021, The Author(s). This is an Open Access article distributed under the terms of the Creative Commons Attribution License (CC-BY) $4.0 \mathrm{https}: / /$ creativecommons.org/licenses/by/4.0/, which permits unrestricted use, distribution and reproduction in any medium, provided the original author and source are credited • DOI: https://doi.org/10.14324/111.444.2041-9015.1286

\section{Open Access:}

Papers from the Institute of Archaeology is a peer-reviewed open access journal.

${ }^{*}$ Correspondence: rosamund.fitzmaurice.17@ucl.ac.uk

${ }^{1}$ Institute of Archaeology, University College London

${ }^{2}$ Department of Anthropology, Northern Arizona University 


\title{
CONFERENCE PROCEEDINGS: TIMELESS SPACES 2019*
}

\section{Play and Purpose: The Relationship Between Patolli and Graffiti at Xunantunich, Belize}

\author{
Rosamund Fitzmaurice, Tia B. Watkins and Jaime J. Awe
}

\begin{abstract}
Patolli is a "dice game" found in Classic and Postclassic period (CE 250900/1000, CE 900/1000-1492) contexts throughout Mesoamerica. This paper provides an overview of ethnohistoric sources and previous archaeological research on patolli to contextualize recent discoveries of boards and other graffiti at the Classic Maya centre of Xunantunich, Belize. We examine the placement of patolli boards relative to graffiti figures within two galleries in the site's north palace complex to understand their relationship with each other and their possible significance within the centre itself. Finally, we present possible interpretations for patolli and graffiti from the Terminal Classic Maya centre of Xunantunich, Belize ranging from commemoration, competition, and divination or ritually related activities.
\end{abstract}

Keywords: Ancient Maya, Aztec, Graffiti, Patolli

\section{Introduction}

The word "Patolli" is a derivative of the Nahuatl word patol (bean), which in most cases are the playing pieces for the board game itself (Źrałka 2014). The earliest documentation of the patolli game comes from ethnohistoric accounts by chroniclers Diego Durán ([1574-1579] 1971) and Bernardino de Sahagún ([1554-1590] 1959) in their descriptions of society under the Mexica-Aztec empire (CE 1428-1519) and into the Colonial period (CE 1519-1821). In recent years, archaeological examples of patolli have been found at many lowland Maya contexts (Swezey and Bittman 1983; Gallegos Gómora 1994; Walden and Voorhies 2017; Źrałka 2014) revealing that

\footnotetext{
"Timeless Spaces: Between Art, Politics, and Vandalism, a Seminar on Ancient and Modern Graffiti was a conference held at the Institute of Archaeology, University College London on the $16^{\text {th }}$ of March 2019, organised by Rosamund Fitzmaurice, Tia Watkins and loannis Nakas. This paper is part of the proceedings of that conference and have been edited by the organisers, with the support of Papers from the Institute of Archaeology.
} 
despite the central Mexican origins of the name used by modern scholars, the game was widespread throughout Mesoamerica as early as the beginning of the Classic Period, around CE 250 ('́rałka 2014).

This paper reviews descriptions of patolli from chroniclers Durán and Sahagún in particular and contrasts it with imagery from the Codex Borgia (early $16^{\text {th }}$ Century), Codex Vindobonensis Mexicanus I ( $14^{\text {th }}$ Century), Codex Vaticanus B/3773 $\left(15^{\text {th }}\right.$ early $16^{\text {th }}$ Century), and Codex Borbonicus (early $16^{\text {th }}$ Century) to examine the cultural associations that patolli held for Mesoamericans. While we accept that significant cultural distinctions existed between the peoples of Mesoamerica, patolli can be approached as a pan-Mesoamerican custom since archaeological examples of the game have been discovered throughout the culture region (Swezey and Bittman 1983; Gallegos Gómora 1994; Walden and Voorhies 2017). In addition to the ethnohistoric sources, we discuss archaeological examples of patolli within the context of lowland Maya graffiti. In all cases when we discuss patolli, whichever their medium (mats, slate, incised into plaster, or otherwise), we assume that humans were able to use them as a physical space to play the game. Finally, this paper presents recently recorded data from Xunantunich, Belize revealing both examples of patolli and graffiti at Structure A13 in Plaza A-III. Patolli boards and graffiti images commonly co-occur at Xunantunich (Mackie 1985; Neff 1995; Yaeger 1997: 33), offering an opportunity for new analyses and interpretations of these features. To accomplish this goal, we draw upon broader patterns evident in ethnohistoric texts and the archaeological record to elucidate the relationship between patolli and graffiti at Xunantunich.

\section{Xunantunich}

Xunantunich is a Classic Maya centre located in west-central Belize within the Mopan River Valley, along the modern border between Belize and Guatemala. Xunantunich reached its political peak at approximately CE 650-750, and subsequently declined around CE 849, based on the last textual evidence found at the centre (Helmke et al. 2010; LeCount and Yaeger 2010: 72-73; Figure 1). The recently recorded patolli and graffiti at Xunantunich were uncovered in Structure A13 of the north palace complex at the site. Structure A13 is a multi-room, audiencia-like structure which separates the elevated Plaza A-III and restricts access from the lower, more open, and public Plazas A-I and A-II. Previous investigators at Xunantunich suggested that Plaza A- 
III was likely constructed to house the site's ruling family around CE 670 (Yaeger 2010: 149). According to Yaeger (2010: 147) this shift occurred either because of limited living space at the traditional royal palace complex, known as El Castillo, or because the north palace was constructed to house a new ruler who had been imposed on Xunantunich by its larger patron centre of Naranjo. While the latter suggestion is possible, Awe and colleagues (2020) argue that eschewing El Castillo as their royal palace would be a significant downgrade for the new rulers of Xunantunich since it would situate them in the shadow of the more imposing royal palace. It also runs contrary to elite Maya tradition which placed great emphasis on situating rulers' residences in places where they emanated power and prestige manifested by their sheer size and monumentality (see Awe 2008). It is therefore more likely that the construction of the north palace complex was associated with an effort to provide additional living space for the ever-growing royal family, "or with increasing administration, courtly prerogatives, and the individual motivations of particular monarchs" at the site (Awe et al. 2020). Additionally, while Yaeger (2010: 156) suggests Plaza A-III was abandoned between $\sim$ CE $750-775$, new evidence at Structure A13 in the form of a hieroglyphic date etched into the building's surface (presented below), suggests a slight extension of the Plaza A-III occupation to CE 790 (Watkins et al. 2018).

In addition to being elevated above Plazas A-I and A-II, Plaza A-III is also fully enclosed by four structures (A10, A11, A12, and A13). This configuration suggests that access into Plaza A-III was likely restricted to those of high status and reflects an architectural configuration that is typical of palace complexes in western Belize (Awe 2008: 167). Because the compound is located at the northern boundary of the Xunantunich ceremonial epicentre and because the palace is far less imposing than El Castillo, we can further assume that those who occupied the more private Plaza A-III compound were likely intermediate elites, possibly related to or in the service of the rulers who resided in El Castillo.

Understanding the importance of public versus private space is essential as we consider the Structure A13 graffiti for it can help us piece together social constructs of the past. Parmington (2011: 21) suggests "privacy" evokes a sense of power and states "privacy [social exclusion] relates to...the power to choose whether or not to associate with others, to participate in shared activities or seek seclusion, to share 
information or withhold it, to communicate information to selected individuals without being observed or overheard". Here we develop ideas put forth by other scholars (Awe 1992, 2008; Martin 2001; Parmington 2011; Walden et al. 2020; Watkins 2019; Watkins et al. 2020) who suggest elite Maya placed value on privacy and internal space, particularly in palatial compounds. In the case of the Maya, greater privacy was achieved by elevating and enclosing their living spaces, and by limiting access therein. The context of both "public" and "private" space at Structure A13, therefore, allows a unique opportunity to assess the contextual significance of graffiti and how such contexts may relate to the social and cultural constructs of the Maya.

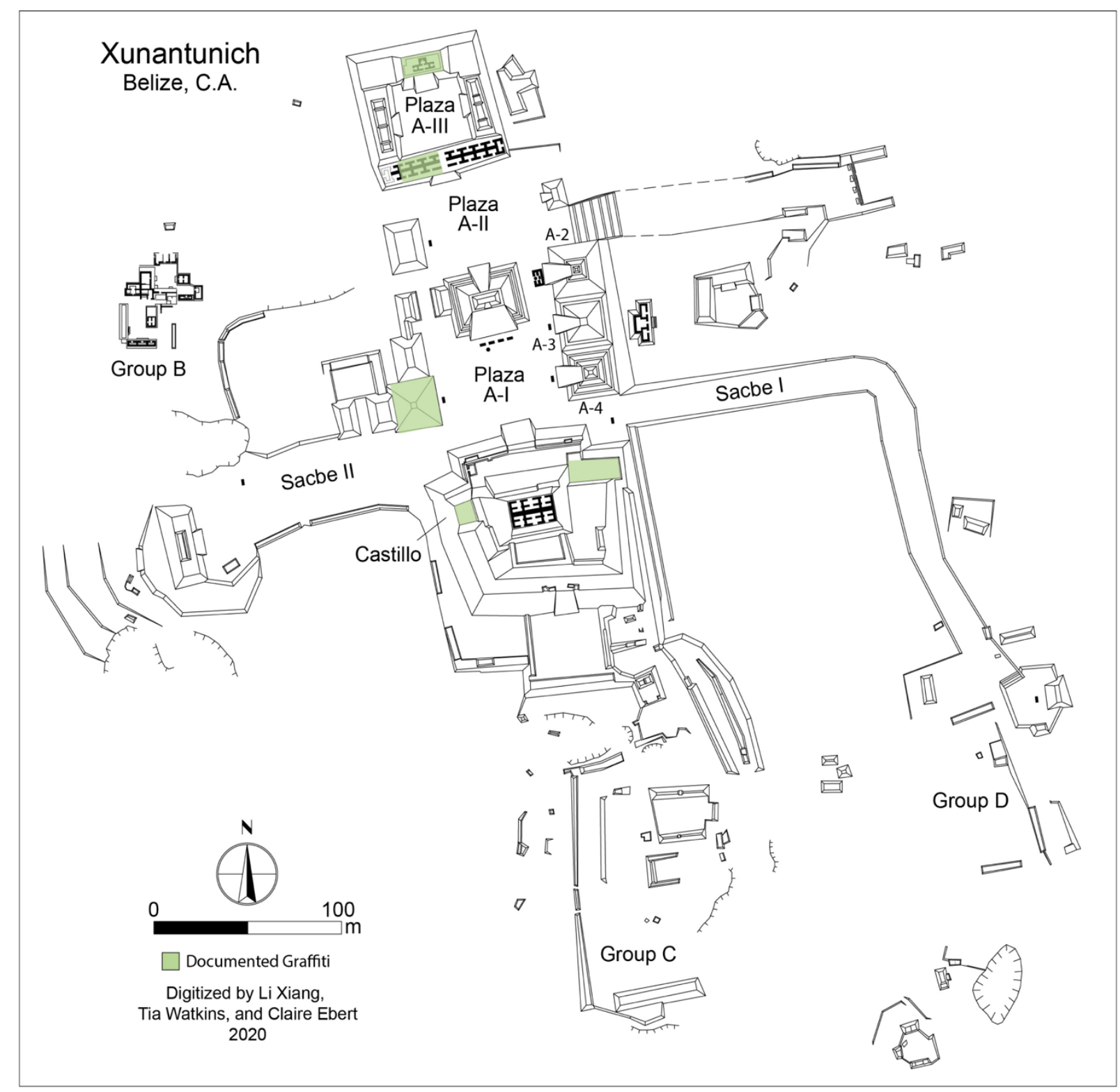

Figure 1: Map of the Xunantunich ceremonial centre showing locations of graffiti (adapted from LeCount and Yaeger 2010: Figure 1.3). 


\section{Patolli in Ethnohistoric and Archaeological Contexts}

Ethnohistoric documents provide some of the best documentary evidence for the use of dice games in Mesoamerica. Diego Durán (CE 1537-1588), a Dominican Friar, and Bernardino de Sahagún (CE 1499-1590), a Franciscan Friar, documented preconquest life among the Aztecs. Durán's perspective on precontact life was derived from the examination of pre-Columbian pictorial codices, whereas Sahagún interviewed people to learn about life before the arrival of the Spanish in the time of the Triple Alliance (Tenochtitlan, Texcoco, and Tlacopan). These chroniclers tended to focus on the upper echelon of Aztec society since pictorial codices largely showed elite practices, and because Sahagún's interviews were limited to the Aztec nobility. Given these limitations, we may assume that patolli was played only by elite individuals. However, we know that it was played by all members of society as Durán ([1574-1579] 1971: 318-319) comments on how the game was played by rich and poor alike.

In ethnohistoric accounts, patolli is often described as a game played on mats which were easily rolled up and carried with the player (Durán [1574-1579] 1971: 303); thus far there are no known patolli mats that have survived in the archaeological record. Mats allowed for portability and made the game an easy pastime for players as they did not require much equipment. Furthermore, it appears that Aztec patolli was not just for the players, but also attracted throngs of spectators (Durán [1574-1579] 1971: 303). Patol beans are usually associated with the playing of patolli (as seen in many codices, Table 1), and could have been used as dice which determined how far pieces moved on the board (Walden and Voorhies 2017). While there are no ethnohistoric accounts of the Maya playing patolli, scholars have noted similar games among the Maya such as Bul documented by chronicler Diego de Landa and other Spaniards (Chuchiak 2003; Verbeeck 1998).

Despite the differences between patolli mats and incised patolli boards, they tend to conform to similar shapes across Mesoamerica, which have been systematically categorized into a typology (Swezey and Bittman 1983; updated Gallegos Gómora 1994: Table 1; further updated Źrałka 2014: 147-149). The most common board shape is a square with a cross in the middle dividing the shape into four equal quadrants (Type I and II; Table 2). The border and central axis of the board appear as laddered pathways; as a result, players may place tokens in the squares, indicating 
their place on the board. This shape is relatively common across Mesoamerica. The image of a square with equal internal quadrants commonly appears in Aztec codices and may be influenced by cosmological constructs present in Mesoamerican culture. The Codex Borgia, in particular, contains pages $(25,27,28)$ which are divided into quadrants with central squared features divided by laddered pathways. Codices also depict the patolli themselves (see Table 1 which shows Post Classic codices from before the time of the Spanish conquest) and various symbols which may be associated with the game. These symbols include playing beans (patol), the ball courts where the Mesoamerican ball game was played, and the maguey plant which was associated with pulque drinking during game playing.

Scholarship investigating patolli has illuminated key social practises surrounding the act of playing the game. Swezey and Bittman (1983: 378-379), for example, note the close association between patolli boards in central Mexican codices and images of pulque. Pulque is a mildly alcoholic beverage produced from the maguey plant (Agave americana), and ethnohistorically has a firm association with various ritual activities (Durán [1588] 1994, note from Heyden: 286). Furthermore, pulque drinking has been associated with use of hallucinogenic drugs which were added to the drink to enhance the experience of the drinker (Durán [1588] 1994: 307, 407, 475; Carod-Artal 2015 : 45-46). The Maya had a similar drink, balché, made from fermenting the bark of the balché tree (Lonchocarpus violaceus) with honey, and was also associated with use of mind-altering substances and ceremonial activity (Carod-Artal 2015: 43-45; Chuchiak 2003: 138). Furthermore, some fermented substances were likely used as enemas by the Maya for ritual and curative purposes (Carod Artal 2015: 44; Lemus 2006). There is no explicit documentation that links the consumption of balché with the playing of patolli, however, some examples of Maya graffiti have been found in the context of vessels which could have been used to hold the drink perhaps suggesting a close relationship between graffiti, games, intoxication, and ritual (Yaeger 2005: 16-20).

The spiritual significance of patolli is heightened when analysing the depictions of the game in Aztec codices. For instance, the Aztec goddess, Xochiquetzal is seen frequently in association with patolli (Swezey and Bitman 1983: 173-179) (Table 1). The codices also often depict figures painted black who could be described as priests. The skin of Aztec priests was dyed black (Smith 2012: 219; Elferink 1999: 437) with 
an unguent called Teotlaqualli made of tobacco, soot, and crushed venomous and poisonous animals including scorpions, snakes, and spiders. The unguent, although primarily used to dye skin, has been associated with hallucinations due to the concentration of tobacco in the mixture (Elferink 1999: 436). Furthermore, the ball game or ball courts are also frequently associated with patolli, and both games contain themes related to Mesoamerican cosmology. For instance, the most common patolli board, the Type II boards described above, may represent the cultural ideologies of how the physical and ancestral planes were divided (Angel Astor-Aguilera 2010: 24; Miller and Taube 1993: 77-78). Patolli also evoke the quad-cross symbols of the Maya (cf. Astor-Aguilera 2010). The ball game, meanwhile, forms a central part of Maya creation myth as established by the Postclassic K'iche' Maya text, the Popol Vuh (Tedlock 1985: 91-198).

Gambling is also associated ethnohistorically with both the ball game and patolli. Durán ([1574-1579] 1971: 318-319) emphasises the relationship between patolli, the ball game, and gambling when he expressed concern regarding the poor playing the game and falling into "slavery" to repay gambling debts (Durán [1574-1579] 1971: 281-282, 301-319). It is important to note the moralising tone of the chroniclers in their reference to gambling and patolli. Both Durán and Sahagún were members of the clergy, with a vested interest in converting the peoples of the Americas to Christianity and, as such, condemned any habits which they considered to be sacrilegious. Walden and Voorhies (2017: 199) point out that chroniclers may have been prone to exaggeration, or alternatively the players may have exaggerated the importance of prosaic gambling in order to deflect attention from the games' ritual connotations which would certainly incur the disdain of the colonial clergy. These criticisms do not negate the association of gambling with patolli playing, but instead highlight the cultural clash of European and Mesoamerican attitudes pertaining to the morality of gambling (Walden and Voorhies 2017: 198-200). The close relationship between gaming and divining in Mesoamerica is regularly considered by scholars (Robin 2012; Verbeeck 1998: 82; Źrałka 2014: 151). Combining the association of patolli with gambling and risk, intoxication, and divination is attractive, but it must be carefully considered in each circumstance to ensure the evidence is clear to make such interpretations. 


\section{Patolli and Graffiti in the Maya Lowlands}

Archaeological evidence of patolli in Mesoamerica is widespread with many examples recorded in the Maya lowlands (Źrałka, 2014: 146). The earliest known examples of patolli, however, come from Teotihuacan, a central Mexican city state, which was at its most influential in the Classic period (Cowgill 2015: 105-112). In the Maya lowlands, Graham (1994: 289-290), and Smith (1977: 359) document rare examples of patolli incised into slate tablets. Smith (1977: 49-63) also provides an example of patolli incised on a ceramic bowl, and Maler $(1901 ; 1903)$ describes examples of patolli carved into wooden lintels. Given these exceptions, in almost all archaeological contexts patolli boards are inscribed in plaster as graffiti. The term "graffiti" carries many Western connotations primarily associated with acts of vandalism. Rather than draw upon our own preconceptions about the intentions of those incising the graffiti, it makes better sense to develop hypotheses about the creation of the material record by comparing the images themselves and their relationship with each other.

The first documentation of graffiti in the Maya area was at Tikal, Guatemala in the late nineteenth century, where Edward Herbert Thompson (1898: 226) described "doodles" left by post-abandonment squatters. Thompson provided little interpretation for his findings, suggesting that they were of little significance. Scholarship in recent decades, however, has firmly refuted the idea that Maya graffiti were meaningless. Recent interpretations pertaining to the motivation of graffiti falls into three broad categories: spiritual, educational, and commemorative (Fitzmaurice 2018: 26-27).

Proponents of the spiritual motivation for graffiti include Webster (1963), Kampen (1978), and Haviland and Haviland (1995); all of whom studied the graffiti of Tikal. Webster suggests that graffiti could be a representation of "curative magic" (1963: 39). In this case, one would etch a representation of a need, be it material or spiritual, to stimulate healing. Kampen (1978), however, associates the etchings with termination rituals. Etchings in this case were part of the destruction of a room, indicating the termination of its function.

The debate surrounding the significance of Tikal graffiti were renewed following an influential paper by Haviland and Haviland (1995) in which they suggest that the graffiti were a product of hallucinogenic states. Importantly, this position suggested 
that the creation of the graffiti was contemporaneous with the occupation of the structures in which they were located, in contrast to previous thoughts of graffiti being a marker for abandonment. The inspiration for their interpretation comes from a paper by Lewis-Williams and Dowson (1988) in which they consider entoptic phenomenon as a cause for abstract forms in African rock art as inspired hallucinations. Hallucinations include entoptic phenomena which suggests individuals experience "geometric visual percepts that include dots, grids, zigzags, nested catenary curves, and meandering lines... Because these percepts are 'wired' into the human nervous system, all people, no matter what their cultural background, have the potential to experience them" (Lewis-Williams 2002: 301). Lewis-Williams coined the term entoptic phenomenon as the word "entoptic" derives from the Greek, meaning “within vision” (Lewis-Williams 2002: 303).

Haviland and Haviland (1995: 297-303) applied the neuro-psychological model of entoptic phenomenon (developed by Lewis-Williams and Dowson 1988; LewisWilliams 2002) to the graffiti at Tikal, concluding that between $66-90 \%$ of the images consist of, or are inspired by, entoptic images. Haviland and Haviland (1995) further suggest these statistics imply that those who created graffiti must have been in a state of hallucinogenic trance, which they explain using the three-stage David LewisWilliams System. Stage One of this system explains the process where an individual experiences visions of simple geometric forms; in Stage Two, the individual visualizes the transition of the geometric forms into more recognisable objects or individuals; during Stage Three the individual sees "iconic" or detailed, complex images (Haviland and Haviland 1995; Lewis-Williams 2002). Using this model, Haviland and Haviland argue that the images present in the graffiti at Tikal are traced from visions projected from the artist's mind onto the physical surroundings of the individual, regardless of other images the author may obscure by overlaying it with new etchings (Haviland and Haviland 1995: 296-298). Notably, Lewis-Williams and Dowson (1988: 205) explicitly state that one does not need to be intoxicated or under the influence of any mind-altering substances to experience entoptic phenomena. While the theory of entoptic forms is acknowledged here, going forward we will categorize any unidentifiable graffiti as "indeterminant" so as to not impose a preconceived influence on the creation of graffiti which we may not understand today. 
Hutson (2011), as well as McCurdy and colleagues (2018) recently proposed an educational motivation for graffiti. Based on a comparison with children's drawings from across cultures, Hutson (2011) suggests that some of the Tikal graffiti were likely made by children. McCurdy and colleagues (2018), in an analysis of graffiti from a palace room in El Castillo at Xunantunich, argue that the medium was a method for training young scribes, similar to the Aztec calmecac (school). This interpretation is attractive as few (if any) "schools" have been identified in the Maya region. While evidence presented by McCurdy and colleagues does suggest repeated images indicate practice, this need not be for the benefit of teaching nor be it exclusive to children, for other activities, particularly rituals, are also associated with recurrent actions. Furthermore, there is little evidence of "high art" created in the form of a graffito, and instead these tend to be on large stone monuments or painted ceramics. It would certainly be unconventional to train scribes on one medium (plaster) and then require them to learn a new medium (stone, ceramic, or paint) when they moved from "amateur" to "professional". The context of the graffiti in El Castillo, a single room measuring approximately $2.9 \mathrm{~m}(\mathrm{~N}-\mathrm{S})$ by $4.3 \mathrm{~m}(\mathrm{E}-\mathrm{W})$ and the walls measuring $2.3 \mathrm{~m}$ in height having been approximately $4 \mathrm{~m}$ before ceiling collapse (McCurdy et al. 2018), also does not support this hypothesis. If one were to use the walls of a palace room as a canvas to train apprentices in art, illustration, and scribe, one would quickly run out of space. Frequent re-plastering could provide the extra space for this sort of regular training but testing has not been carried out to determine the frequency of re-plastering events in the rooms.

Recently, many studies of pre-Columbian graffiti have pointed to memorialisation and commemoration as a motivation for creating the images. Źrałka (2014), Źrałka and Hermes (2009), Patrois (2013), Navarro-Castillo and colleagues (2017), Olton $(2015 ; 2018)$, and Watkins and colleagues $(2018 ; 2020)$ have interpreted graffiti as the product of documenting certain events, individuals, and dates for the purpose of remembrance, though the "importance" of these commemorative etchings remains somewhat of a mystery. Źrałka and Hermes (2009) show that graffiti at the sites of Nakum and Yaxhá in Guatemala form narrative scenes, mirroring the topography of the sites in which they are found. Patrois (2013) explains how graffiti at Río Bec, Mexico was found in all class contexts, from elite to common, and formed a commemorative collection of images given the intimate contexts in which they are found. The interpretations of graffiti at Plan de Ayutla, Mexico, by Navarro-Castillo 
and colleagues (2017), mirror those of Patrois (2013), but instead are set in an elite residence; however, they do indicate that one graffito may be of a spiritual significance (Navarro-Castillo et al. 2017: 7). Finally, Olton $(2015$; 2018) points out images which seem to be mirroring depictions of the Protector-Ruler in Lintel 3 to argue that some graffiti at Tikal is likely politically motivated. Olton firmly associates the graffiti with an elite contemporary audience based on the location of the graffiti in the site core and its subject matter.

It is important to note that the above interpretations are not mutually exclusive. One can, for example, be inebriated while commemorating an event, while also teaching children how to commemorate an event. All sorts of combinations can be present, overlapping, or alone. We examine relationships between graffiti and the associated patolli to argue that graffiti were associated with the social practices surrounding the patolli game.

\section{Patolli and Graffiti at Structure A13, Xunantunich}

Graffiti presented in this study were documented by the Xunantunich Archaeological and Conservation Project (XACP) during the 2017 and 2019 field seasons at Structure A13 within Plaza A-III (Watkins et al. 2018; Watkins et al. 2020; Figure 2). The patolli and graffiti are found on the terminal phase architecture and were possibly created by the original inhabitants given the high level of dedication and skill shown in the execution of the images and the presence of a potentially commemorative date glyph which reads $11^{\text {th }}$ October CE 790, clearly within the occupational timeframe of the site, the last epigraphic date associated with the site being CE 849 from Stela 1 and Altar 1 (Helmke et al. 2010: 98, 113-120). However, given the level of preservation of the graffiti and patolli we may speculate that both contemporary and peri-abandonment populations could have partaken in creating the graffiti, following the suggestions of Patrois at Río Bec (2013). Two patolli boards in the Northern Gallery in particular are found on the room's floor (G12-3 and G13-1) and thus would have been especially vulnerable to weathering because of footfall, suggesting their survival was made possible because they were later additions to the corpus. Alternatively, given the preservation and close association of all the graffiti with each other it is possible that all of these images were made as part of peri-abandonment activities. 
A total of twenty-four incised images uncovered by XACP in 2017 (Watkins et al. 2018) and 2019 (Watkins et al. 2020) were located in the northern and southern galleries of Structure A13, the southernmost structure in the Plaza A-III elite compound (Table 2). In 2017, graffiti images of persons and game boards were also found in Rooms 6, 7, and 8, while in 2019 graffiti were found in Rooms 11, 12, and 13 (Table 2). All of the rooms excavated revealed patolli or patolli-like graffiti on the benches and in some cases on the floors, (Room 11 and Room 12; Watkins et al. $2018,2020)$ totalling twelve patolli in all. There are also three individuals depicted that have been identified as warriors and priests by Watkins and colleagues (2018) as well as the date glyph mentioned above and detailed below.

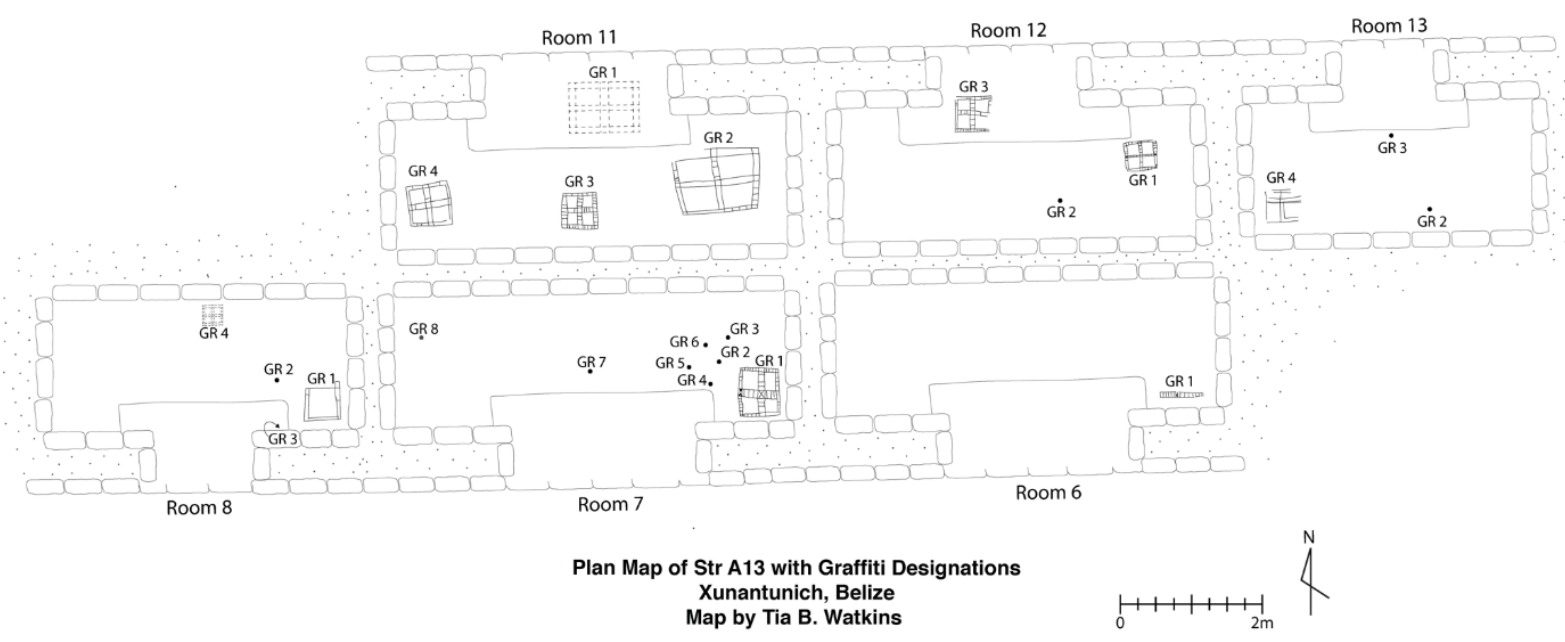

Figure 2: Map of Structure A13 showing the location of each graffiti and patolli found during the 2017 and 2019 field season.

\section{Southern Gallery (Rooms 6, 7, and 8)}

There is one graffito within Room 6 (G6-1) consisting of an incomplete or heavily eroded patolli board on the eastern corner of the bench surface behind the eastern door jamb. While we could regard this form as indeterminant, given the pattern of patolli in Room 7 and Room 8, we feel confident describing it as a partial or eroded patolli. There are eight graffiti within Room 7 . While the patolli board can be seen clearly on the eastern side of the bench in the same position as the patolli in Room 6, there are four other recognisable figures. Watkins and colleagues (2018) identify G74 as a priest possibly looking into an obsidian mirror. G7-6 is thought to be a warrior holding an upright spear and wearing an elaborate headdress (Watkins et al. 2018). G7-7 is the 11 Ajaw glyph bearing a date of 11 October CE 790 (Watkins et al. 2018; 
see also Helmke and Źrałka, this volume). G7-8 is another warrior holding a downturned spear behind them. While G7-2, G7-3, and G7-5 might be incomplete or heavily worn images, they are unfortunately not fully recognisable. G7-8 is situated on the western side of the bench, farthest from the patolli board, and G7-7 is toward the middle of the bench slightly west of centre. G7-4, the priest and the remaining indeterminant images are closest to the patolli board, clustered to the west, all within a metre of the board. Room 8 contains three graffiti. One incomplete patolli board (G8-1) is on the eastern side of the bench in the corner closest to the entrance. G82 is indeterminant in form and is situated towards the centre of the bench, slightly towards the east of the room. G8-3 is on the southern wall above the partial patolli board, it is the only image in this gallery to make use of a ground line (an incised line indicating the floor or ground upon which the image "stands") and appears to show two legs and possible garment hanging to the ankles, but it is only a partial image.

\section{Northern Gallery (Rooms 11, 12, and 13)}

Room 11 does not contain any graffiti images, only patolli boards. They are relatively evenly placed throughout the room. G11-2 on the east side of the bench; G11-3 is toward the centre of the bench and is the most complete of the boards in the room; G1-4 is on the west side of the bench; G11-1 is not on the bench but is rather on the floor at the entrance to the room. There are three graffiti in Room 12. G12-1, a patolli board, is on the eastern side of the bench. G12-2 is positioned slightly to the east of the centre of the bench. G12-2 is likely a graffito (sing.) because of the presence of ground lines (lines representing the floor or ground upon which the possible temple "stands"), though it may also be interpreted a partial or poorly executed patolli board (Watkins et al. 2020). G12-3 is a patolli board positioned on the floor in front of the bench, slightly to the west of the entrance. There are two graffiti images and one patolli board in Room 13. G13-2 is most likely a seated figure with a headdress (Watkins et al. 2020), however, the lower half of the image is not clear and thus this assessment is not certain. G13-2 is positioned slightly to the east of centre towards the back of the bench. G13-3 is a collection of lines which do not appear to coalesce into a decipherable image. G13-3 is also positioned toward the centre of the bench, but it is closer to the entrance than G13-2. Finally, G13-4 is a partial patolli board in the back western corner of the room on the bench. 


\section{Interpretation of the Xunantunich Patolli}

The graffiti recorded in Structure A13 at Xunantunich provides important information about the people who occupied the space and who incised the graffiti and patolli in the rooms. The combination of human figures and patolli is a wellrecorded pattern at Xunantunich, particularly in El Castillo (McCurdy et al. 2018; Yaeger 2005). Those in Structure A13, however, differ from those in El Castillo in the frequency of the patolli boards and their associated anthropomorphic figures. These differences, we believe, may likely reflect information about the individuals who produced the images in Structure A13. The images in the Southern Gallery (Rooms 6, 7, and 8), for example, show that the producers of the images were knowledgeable and skilled enough to etch a detailed portrait of an individual with the possible title Ajk'ubuun (sometimes spelled Aj k'ubun) as well as an associated calendar date (Watkins et al. 2018). The Classic Maya title Ajk'ubun has been interpreted by various epigraphers as "One who keeps, guards" or "One who worships, venerates" (Jackson and Stuart 2001: 226; Zender 2004: 194). This association with a "priestly" individual indicates that the people responsible for etching the figure were likely of high status, and that the graffiti and patolli in the Southern Gallery likely served divination purposes.

\section{Patterns in Patolli Placement at Structure A13}

Ten new, complete, patolli were found during the 2017 and 2019 excavations with two partial or incomplete patolli. Patolli found in the Southern Gallery rooms (i.e., the rooms facing the public access Plaza A-II) each measure approximately $30-40 \mathrm{~cm}$ and were all etched into the bench surface behind the eastern door jambs of the rooms, reducing space for additional players and onlookers. To include more people in the activity the more logical placement of the board would be in the centre of the bench surface or perhaps the floor, where one could fit more people. There is one significantly smaller board in Room 8, measuring approximately $10 \mathrm{~cm}$ square, but it is certainly an exception compared to the Structure A13 patolli assemblage as a whole. Indeed, there is also evidence of a curtain holder in Room 8, allowing for a curtain to be hung and thus drawn to obscure view for any onlookers. We can consider this priority for privacy in the other rooms facing Plaza A-II and assume that these curtain holders would have also been present in other rooms to provide a similar level of privacy. Given the regular placement of the patolli in the Southern Gallery we argue that they were deliberate. Positioning the patolli in the east of the rooms may have 
even indicated when it was being played since in the evenings the setting sun in the west would have illuminated the patolli boards on the eastern side of the rooms (Fitzmaurice 2018: 94). Placing these boards in convenient places for play indicates a desire for long term use of patolli and, possibly, specialised use of this area for its play.

In contrast to the Southern Gallery rooms, the graffiti and patolli in the Northern Gallery (Rooms 11, 12, and 13) are not associated with depictions of elite individuals or any hieroglyphic text. The graffiti assemblage in the Northern Gallery are also not uniformly distributed in the room but rather haphazardly placed over the available space. The patollis are etched into one room floor, frequently on the bench surfaces, and one example is even located on the terrace surface near the entrance of Room 13 (Watkins et al. 2018). In this context, we can consider several explanations for the differing placement of boards. It is important to note that the Southern Gallery directly faces and is exposed to the grand Plaza A-II, which would have been used for public gatherings, whereas the Northern Gallery faces internally to the more private Plaza A-III. The differences in patolli placement and patterns between more publicly viewed space versus more private space could be a direct reflection of "keeping up appearances" (Watkins et al. 2020). Because of the private nature of Plaza A-III, the need to restrict the number of players or onlookers may have been less important.

\section{Commemoration}

Watkins and colleagues (2018) suggest that the images in Room 6, Room 7, and Room 8 might reflect images or events observed by those occupying the rooms. This interpretation is associated with the position of the rooms facing out onto the large public Plaza A-II where large-scale public events would have occurred. Additionally, the Ajaw date glyph may have been incised as a date marker for a significant occasion. Limitations to this interpretation include the fact that none of the graffiti in the rooms consist of a narrative scene (sensu Źrałka and Hermes 2009; see also Źrałka 2014: 165-175), but rather they are all individual images. While some of the graffiti are clustered together, they do not follow ground lines nor are they oriented in the same direction. Finally, this interpretation does not fully account for the presence of the patolli and their consistent placement in the three rooms of the Southern Gallery. While the patolli may have simply been for casual play and the graffiti for 
commemoration, it seems unlikely that the patolli and graffiti would not be more significantly associated with each other.

\section{Competition and Gambling}

It is very likely that, among the Classic Maya, patolli was treated as a serious and competitive game as it was in later Aztec society. As mentioned above, depictions of patolli in ethnohistoric documents and codices often associate patolli with the Mesoamerican ball game. The Mesoamerican ball game, of course, is rooted in spiritual and cosmological values as well as socially important constructs such as competition, camaraderie, honour, success, and defeat. The close association of patolli and the ball game presents interesting questions about the social constructs surrounding patolli and games in general. Using the data from Structure A13, it is possible that patolli could have served as a formal competitive game where individuals could win items of value and onlookers could wager on the players and the game's outcome. While Aztec ethnohistoric sources emphasise the presence of spectators (as was also the case for the ball game (cf. Stark and Stoner 2017), most patolli in the Maya area have been found in largely private contexts including temples and residential rooms (Walden and Voorhies 2017: 210; Źrałka 2014: 151); it is both uncommon and interesting that one patolli board in front of Room 13 was found on the terrace, and therefore would have been well positioned for onlookers. This idea is not new in the discourse surrounding patolli, however, in the case of Structure A13 we might be seeing an example of patolli boards with limited accessibility that could be used for practice and training among residents of Plaza A-III (Structure A13 Northern Gallery). In contrast, the less private nature of the Southern Gallery could represent a more public space where official "matches" could be held. This compliments other hypotheses which suggest that patolli could serve as a pastime activity (Watkins et al. 2018; Źrałka 2014: 151) since the game could likely be both casual and informally played by anyone and also a game played in organised competition similar to chess today. The ideas presented here can be further supported if other comprehensive assemblages of patolli are documented at other Maya centres and are analysed spatially regarding their association with public and private space. 


\section{Divination and Hallucination}

Unlike Tikal, Structure A13 at Xunantunich displays very few examples of indeterminant forms that correlate to those documented by Haviland and Haviland (1995), however, we still consider the possibility of both divination and hallucination (potentially but not necessarily brought about through intoxication) practices in association with the Structure A13 graffiti given the ethnohistorically documented relationship between these activities. Additionally, the association of Structure A13 with the depicted Ajk'ubum and the date glyph could suggest the building was occupied or used by a priestly/scribal elite group. If this is the case, patolli could have likely been used for ritual or divination purposes. Given that many Maya patolli are associated with temples (Walden and Voorhies 2017: 210; Źrałka 2014: 151), this ceremonially-related function is consistent with their occurrence in other contexts. This interpretation is further supported by the associated graffiti figures, and by the iconographic similarities between the patolli board and Classic Maya cosmology. It is possible, therefore, that the board may have been "themed" to represent the Maya cosmos and as such may have been associated with divination. Furthermore, graffiti and patolli have been previously closely associated with hallucination and ritual within Plaza A-III. Yaeger (2005: 16-21) identified graffiti and two patolli in Structure A11, the northern most building in Plaza A-III opposite of Structure A13. One graffito in Structure A11 is of an individual potentially masturbating or piercing his penis in a bloodletting ritual (our interpretation of the image; image from Yaeger 2005: 18). The chambers in which this graffito and associated patolli were found also contained ceramic vessels which are thought to have been long term storage jars for dry goods or liquids (Yaeger 2005: 18).

Chuchiak writes extensively about the Maya ritual use of balché, in particular its association with the Maya cosmos (Chuchiak 2003: 145-146). He also emphasises that the drink gained a new notoriety after the arrival of the Spanish and after it was outlawed, which curiously increased the prestige of those who cultivated the balché tree and brewed the drink (Chuchiak 2003: 142-143). Much of the drinking Chuchiak describes is closely connected to community, social hierarchy, and even reconciliation after altercations (2003: 148-149, 152-153). Thus, inebriation was not an uncommon aspect of the ritual life of the Maya, nor potentially that of people playing the game. It is possible, therefore, that the ceramic vessels in Structure A11 could have contained balché that was consumed by players or ritual participants in the room 
where the patolli and associated graffiti were found. This hypothesis requires supplementary analysis of the ceramic materials recovered including trace element determination and residue analysis, both of which are currently out of the scope of this research.
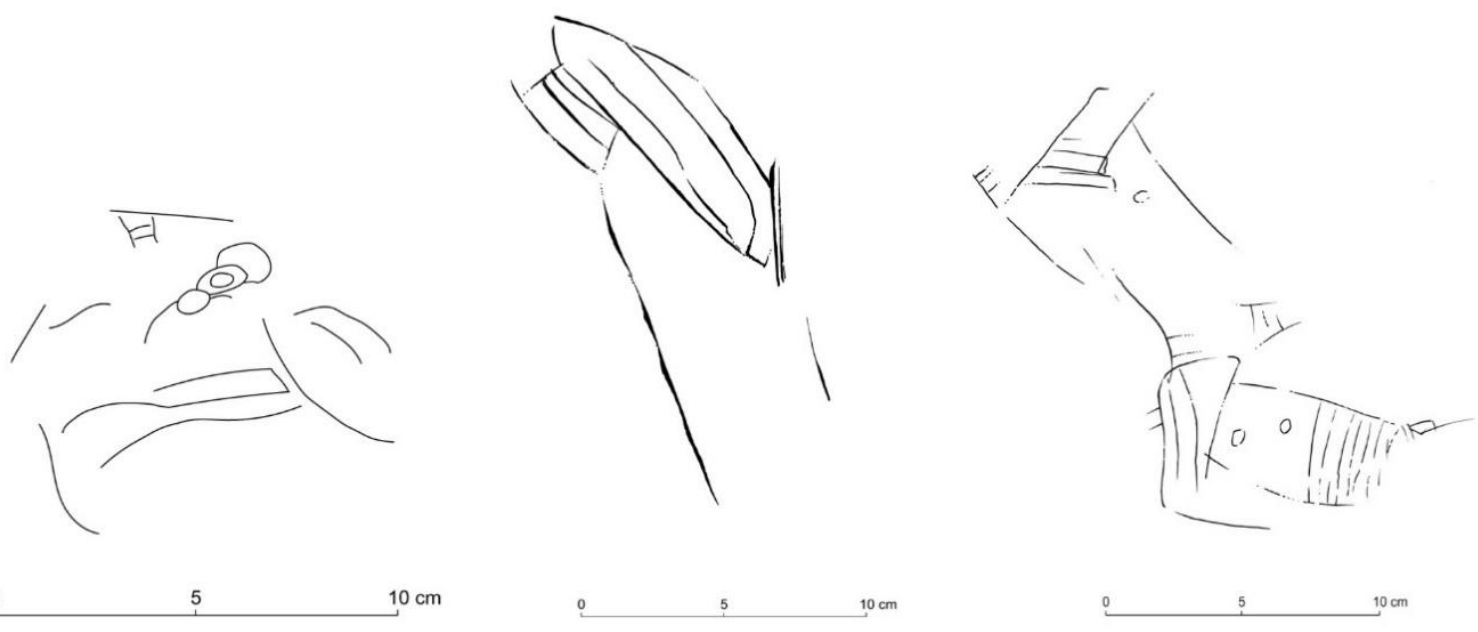

Figure 3: Examples of undetermined graffiti forms found within the Structure A13 graffiti assemblage.

\section{Conclusions}

In this paper we have explored the diverse understandings of patolli and graffiti alike. We have considered formal practice and competition, commemoration, divination, and hallucination in our assessment of the Structure A13 graffiti assemblage. Here we suggest two separate functions of patolli at Structure A13 based on their spatial context, associated images, and commonalities found within the literature. Due to the intentional placement pattern of the patolli, the possibility of the boards being closed off by curtains, the uniform size of the boards, and the presence of priestly depictions and hieroglyphic text, we suggest the patolli found in the Southern Gallery of Structure A13 was likely associated with divination and/or ritual use. The depictions of patolli and use of the patolli form in the codices (mentioned above) in association with depictions of priestly individuals also reinforces the hypothesis that patolli certainly carried a spiritual/cosmological significance.

In contrast, the patolli found in the Northern gallery of Structure A13 certainly do not conform to an obvious pattern in spatial local, nor do the size of the boards themselves. Because there is no pattern in placement, no significant associated 
imagery (frequency and depictions themselves), we suggest the patolli found in the Northern gallery was likely used for casual play or practice. Likewise, the haphazard placement of the boards may reflect events that resulted in the disorganized etching of images found at Tikal. As mentioned above, inebriation certainly played an essential role in Mesoamerican society including ritual and competitive events, thus the exclusion of Haviland and Haviland's (1995) hypothesis of hallucination would do a disservice to the topic at hand. Based on the random placement of the boards in the Northern Gallery and findings by Yaeger (2005) in the building opposite, we suggest intoxication may be a contributing factor during the creation and playing of patolli in the Northern gallery at Structure A13. While we don't exactly know how intoxication was socially perceived in Maya society, the more private setting of Plaza A-III may have provided a secure space where its occupants could enjoy drink and game without the worry of onlookers.

It is, nevertheless, difficult to accurately determine whether these patolli boards were meant for long-term play or whether they simply reflect expedient acts. In other words, does the Late Classic hieroglyphic date etched into Room 7 suggest that the graffiti and patolli boards were meant for a contemporary audience or were they more likely the products of peri-abandonment activities at the sites? It is unlikely, for example, that those creating graffiti expected their images to have any longevity particularly given their low relief and the regular re-plastering of floor surfaces in Maya structures. On the other hand, evidence of the last textual evidence at the site suggests abandonment sometime after AD 849 (Helmke et al. 2010), and thus it is possible that some of the graffiti etchings occurred during the site's occupation and some around the time of or after the site abandonment. In the end, interpretations of patolli and graffiti images must be made based on the context in which they are found. For these reasons, we strongly suggest that functional interpretations not be generalised for the entire corpus of lowland Maya graffiti. Further research may reveal that graffiti was used for different purposes in different areas of the Maya world, or even within individual centres such as Xunantunich. 
Acknowledgements: The authors would like to thank the Institute of Archaeology and Institute for Social and Cultural Research, Belize for their support of the Xunantunich Archaeology and Conservation Project and the Belize Valley Archaeological Reconnaissance Project (BVAR). We also acknowledge the generous support from the Tilden Family Foundation, whose dedication to heritage preservation and management has made this research possible. We would like to acknowledge the BVAR co-directors Julie Hoggarth and Claire Ebert for their guidance and mentorship. Appreciation is due to Christophe Helmke, who provided original illustrations and expert analyses of the Structure A13 graffiti so that this research could be better informed. We would like to thank the Ancient Americas department in the Los Angeles County Museum of Art for their high-quality photos of the codices Borgia, Vatticaus $(3773 / \mathrm{B})$, and Borbonicus and to the Österreichische Nationalbibliohek for providing high quality images of the Codex Vindobonensis. We also want to thank John P. Walden for taking the time to provide much feedback and critical advice. The authors also give thanks to the reviewers of this paper who provided key critical advice. Finally, we would like to express our endless gratitude for the citizens of Belize and specifically to those from the San Jose Succotz village who helped excavate, clean, and document the very fragile graffiti; your dedication and patience to tedious work is greatly appreciated. 


\section{Tables}

Table 1: Excerpts from codices which depict patolli.

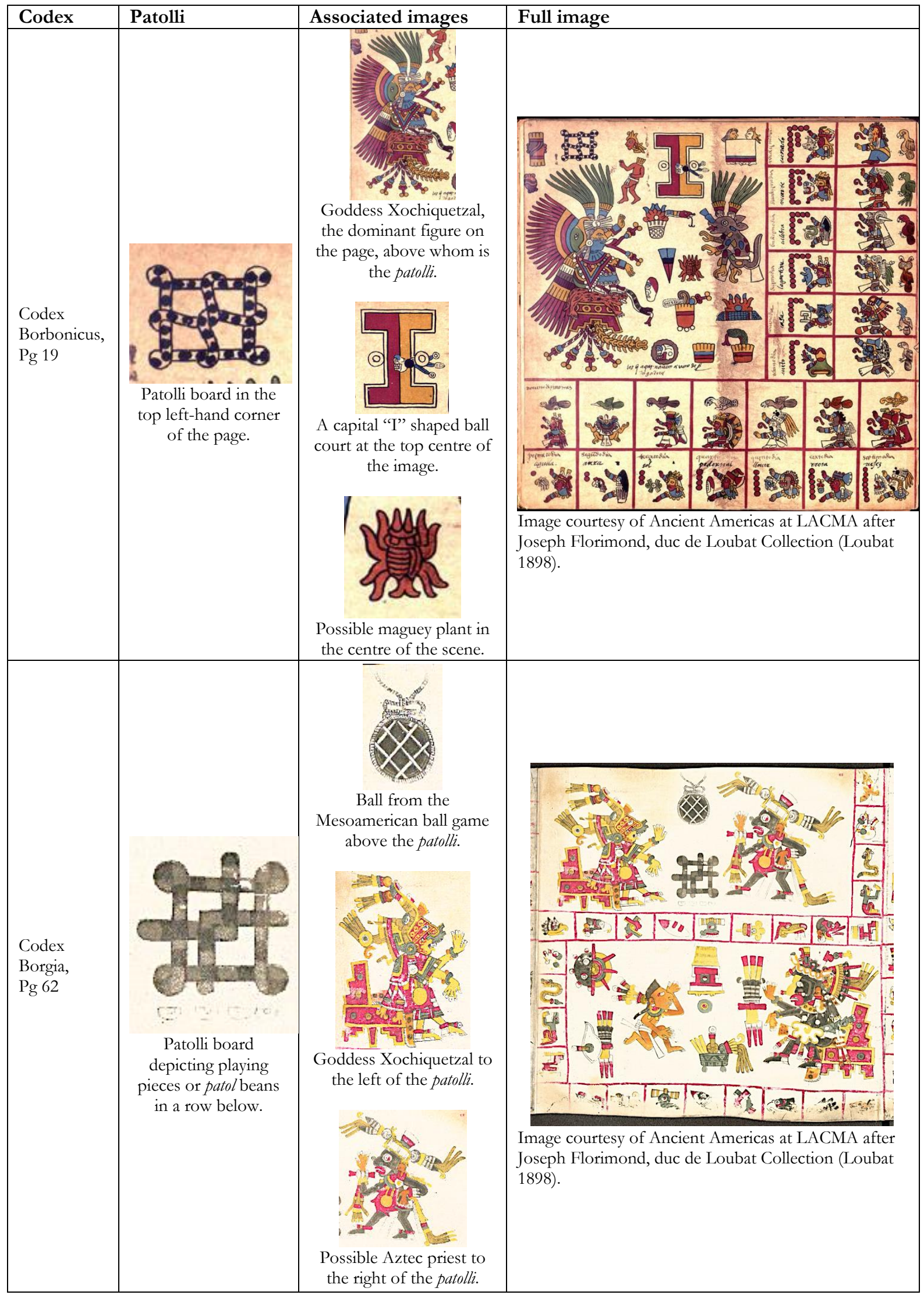




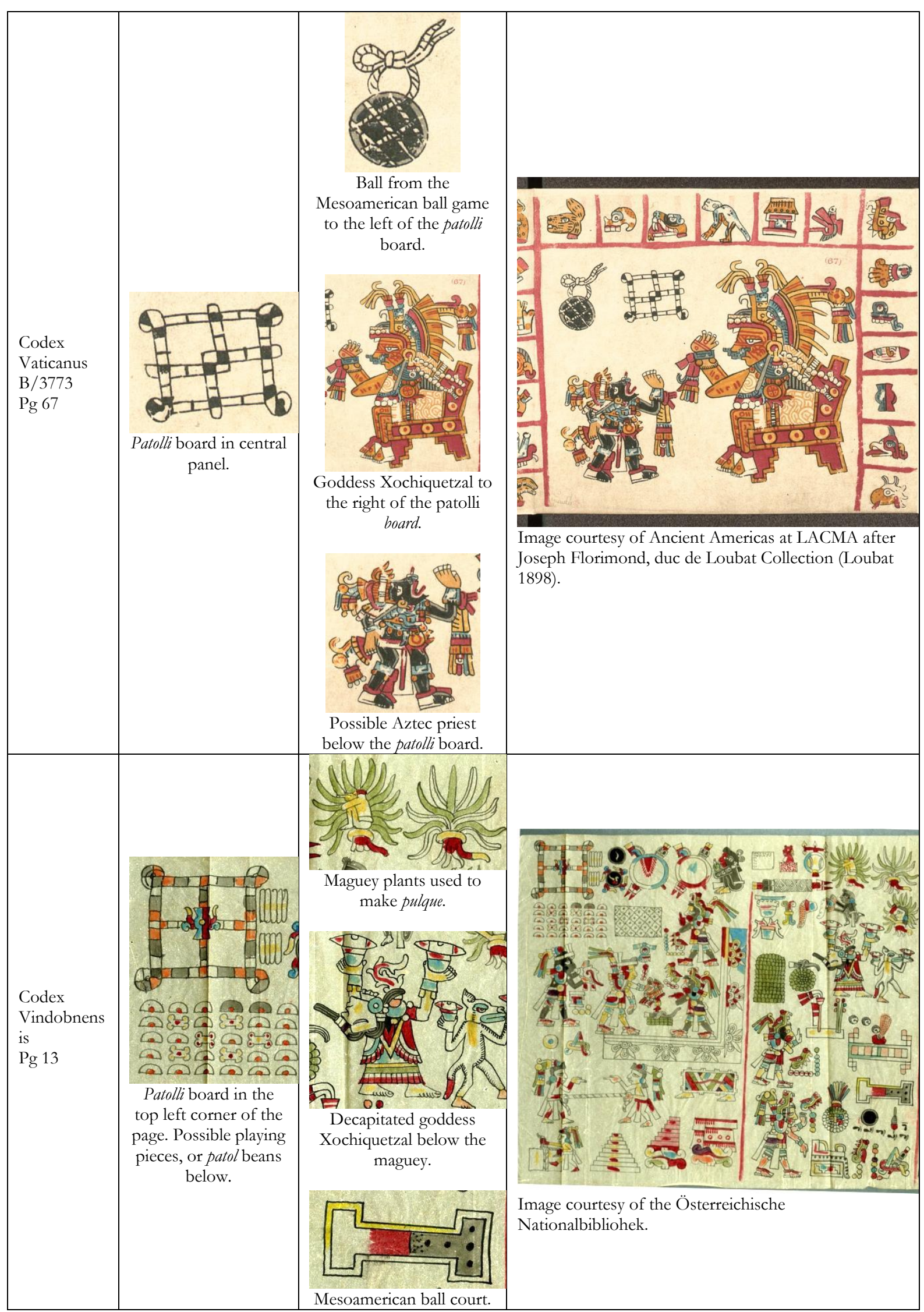




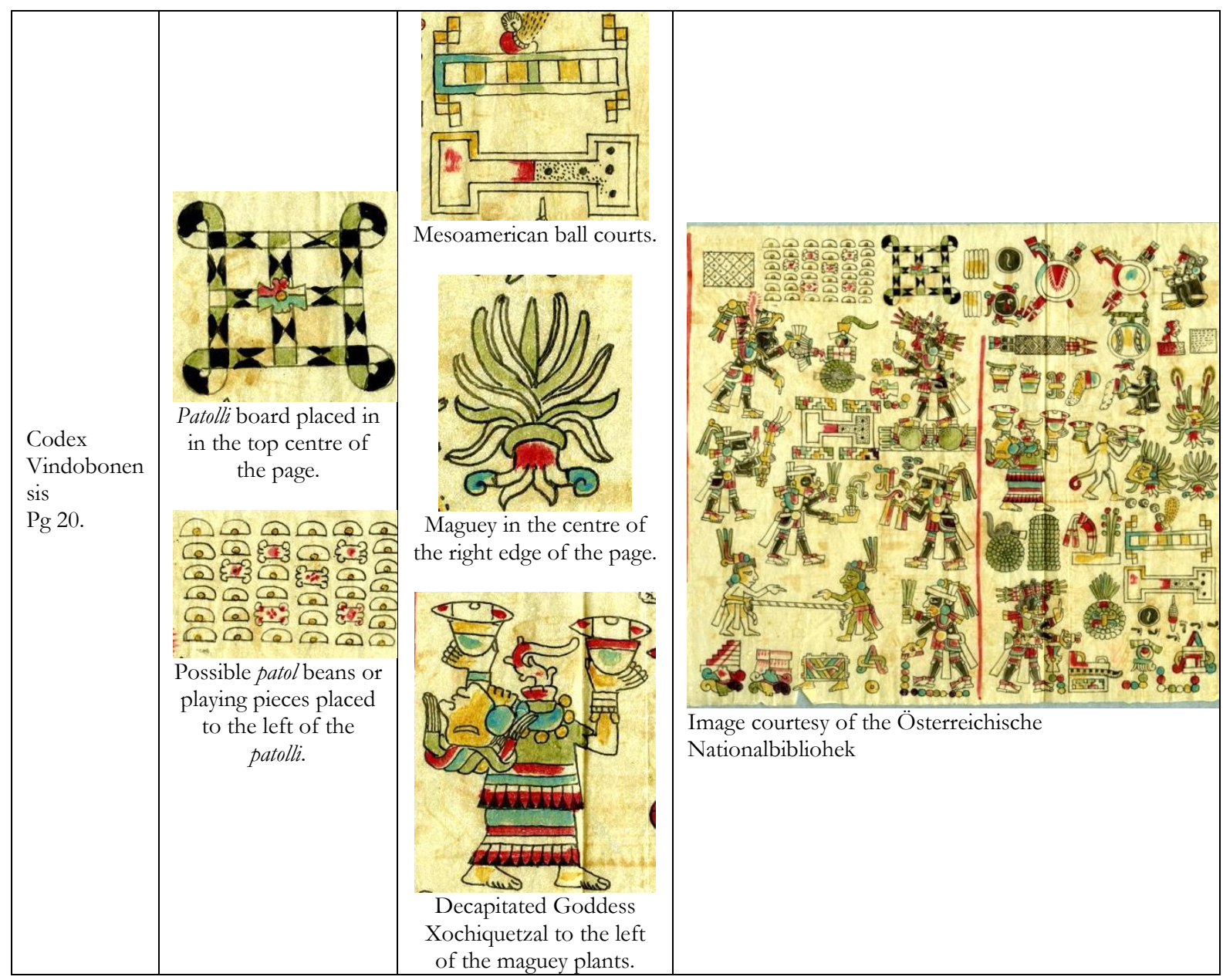


Table 2: Graffiti and patolli found in Structure A13.

\begin{tabular}{|c|c|c|c|c|}
\hline $\begin{array}{l}\text { Room/Catalogue } \\
\text { No. }\end{array}$ & Graffiti/Patolli & Context & Description & Reference \\
\hline $\begin{array}{c}\text { Room } 6 \\
\text { G6-1 }\end{array}$ & 11.1 & $\begin{array}{l}\text { Bench surface, } \\
\text { behind eastern } \\
\text { door jamb }\end{array}$ & $\begin{array}{c}\text { Partial or } \\
\text { eroded Patolli } \\
\text { Board }\end{array}$ & $\begin{array}{l}\text { Illustrated by Christophe } \\
\text { Helmke, Watkins et al. } 2018\end{array}$ \\
\hline $\begin{array}{c}\text { Room } 7 \\
\text { G7-1 }\end{array}$ & A & $\begin{array}{l}\text { Bench surface, } \\
\text { behind eastern } \\
\text { door jamb }\end{array}$ & Patolli Board & $\begin{array}{l}\text { Illustrated by Christophe } \\
\text { Helmke, Watkins et al. } 2018\end{array}$ \\
\hline $\begin{array}{l}\text { Room } 7 \\
\text { G7-2 } \\
\text { G7-3 }\end{array}$ & 夏 & Bench surface & $\begin{array}{c}\text { Elderly } \\
\text { individual with } \\
\text { large } \\
\text { headdress, } \\
\text { associated } \\
\text { hook-like } \\
\text { object }\end{array}$ & $\begin{array}{l}\text { Illustrated and Interpreted by } \\
\text { Christophe Helmke, Watkins et } \\
\text { al. } 2018\end{array}$ \\
\hline
\end{tabular}




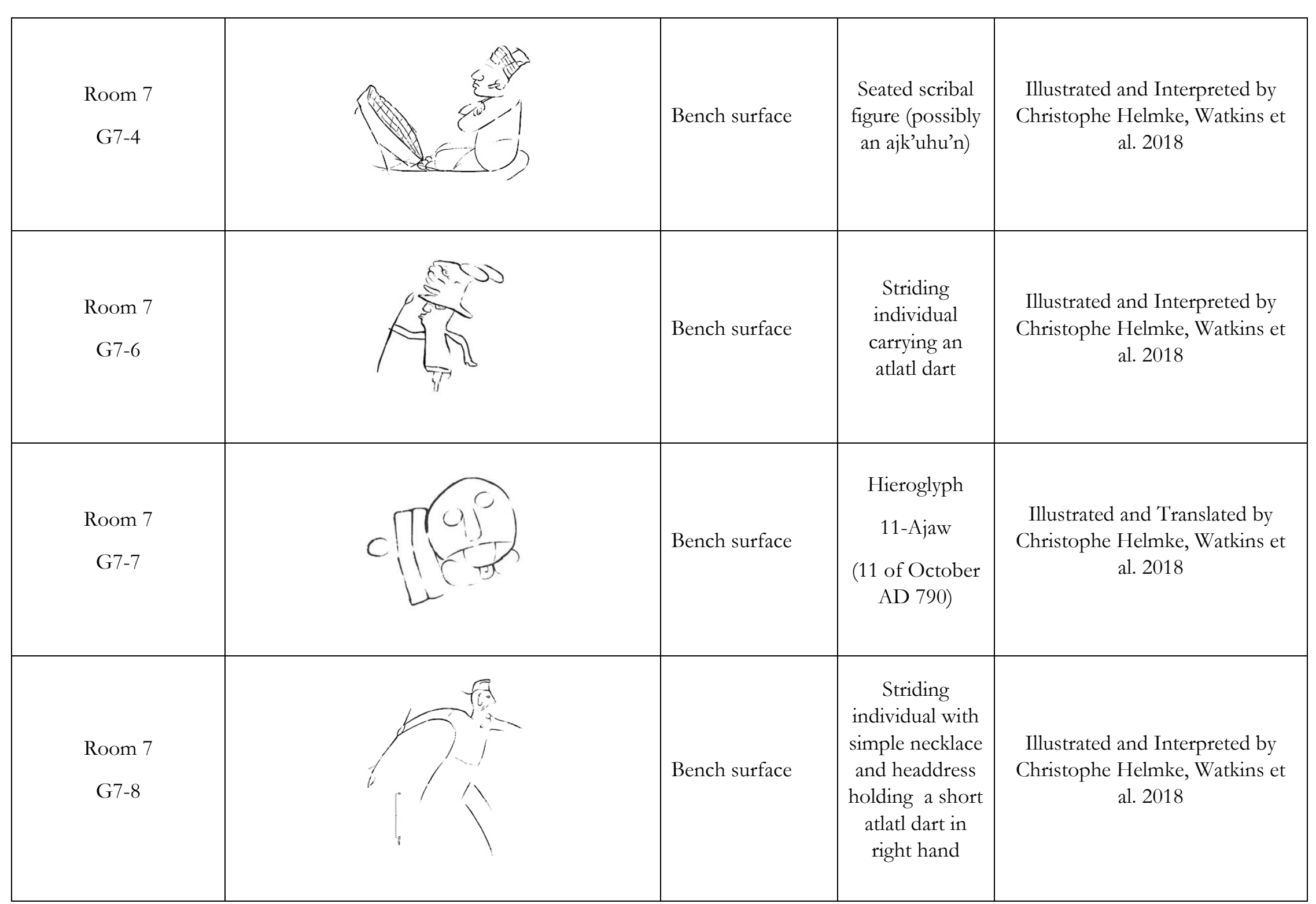




\begin{tabular}{|c|c|c|c|c|}
\hline $\begin{array}{c}\text { Room } 8 \\
\text { G8-1 }\end{array}$ & $\cdots$ & Bench surface & Patolli Board & $\begin{array}{l}\text { Illustrated by Christophe } \\
\text { Helmke, Watkins et al. } 2018\end{array}$ \\
\hline $\begin{array}{c}\text { Room } 8 \\
\text { G8-3 }\end{array}$ & & $\begin{array}{l}\text { Interior wall of } \\
\text { eastern door jamb }\end{array}$ & $\begin{array}{l}\text { The lower } \\
\text { portion of an } \\
\text { individual's legs } \\
\text { showing the } \\
\text { end of a } \\
\text { loincloth } \\
\text { Cord holder } \\
\text { placed below } \\
\text { graffiti G8-3 }\end{array}$ & $\begin{array}{l}\text { Illustrated and Interpreted by } \\
\text { Christophe Helmke, Watkins et } \\
\text { al. } 2018\end{array}$ \\
\hline $\begin{array}{c}\text { Room } 8 \\
\text { G8-4 }\end{array}$ & Digital Illustration Unavailable & Bench surface & Patolli Board & Watkins et al. 2018 \\
\hline $\begin{array}{c}\text { Room } 11 \\
\text { G11-1 }\end{array}$ & Digital lllustration Unavailable & Room floor & Patolli Board & Watkins et al. 2020 \\
\hline
\end{tabular}




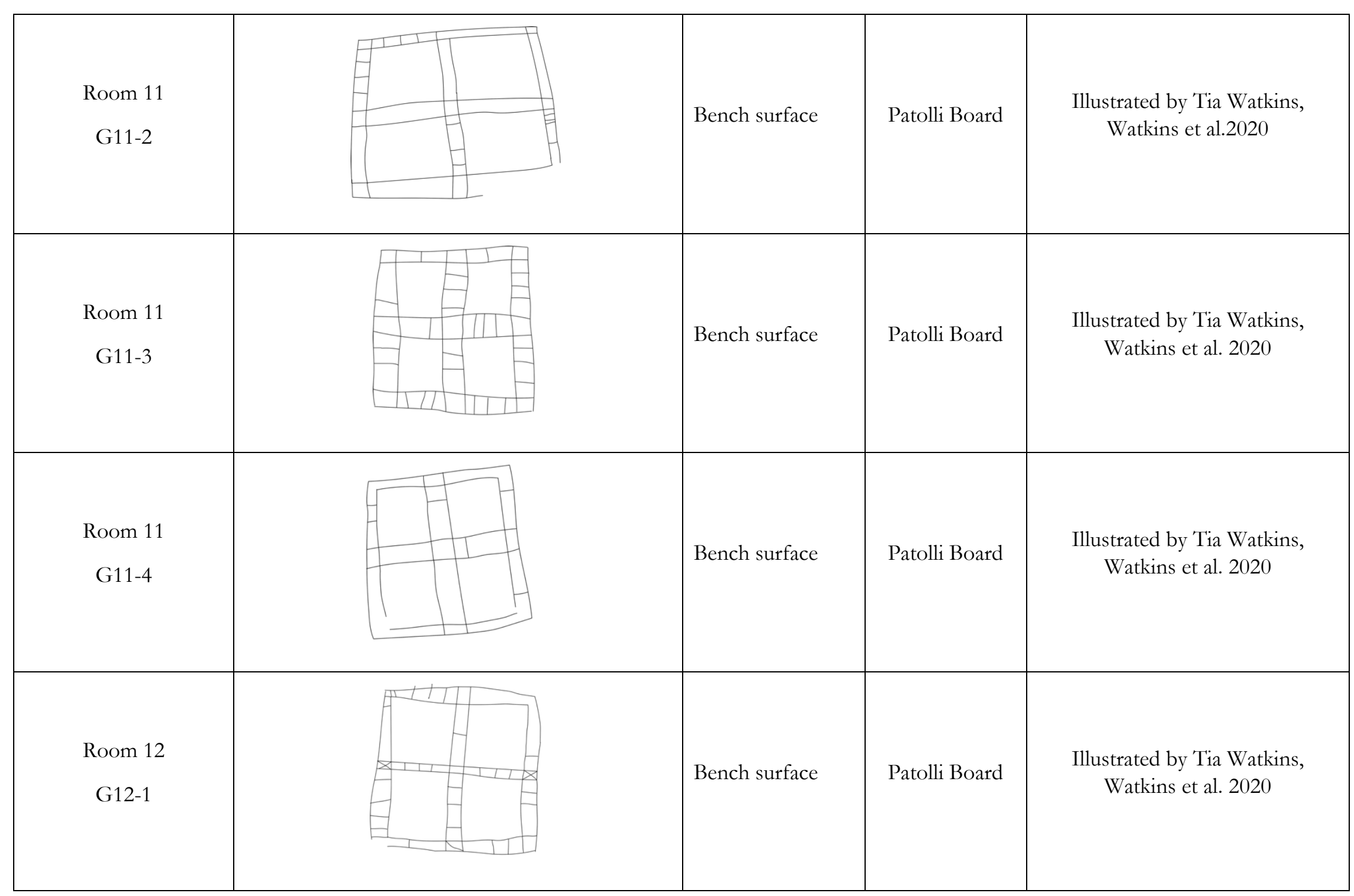




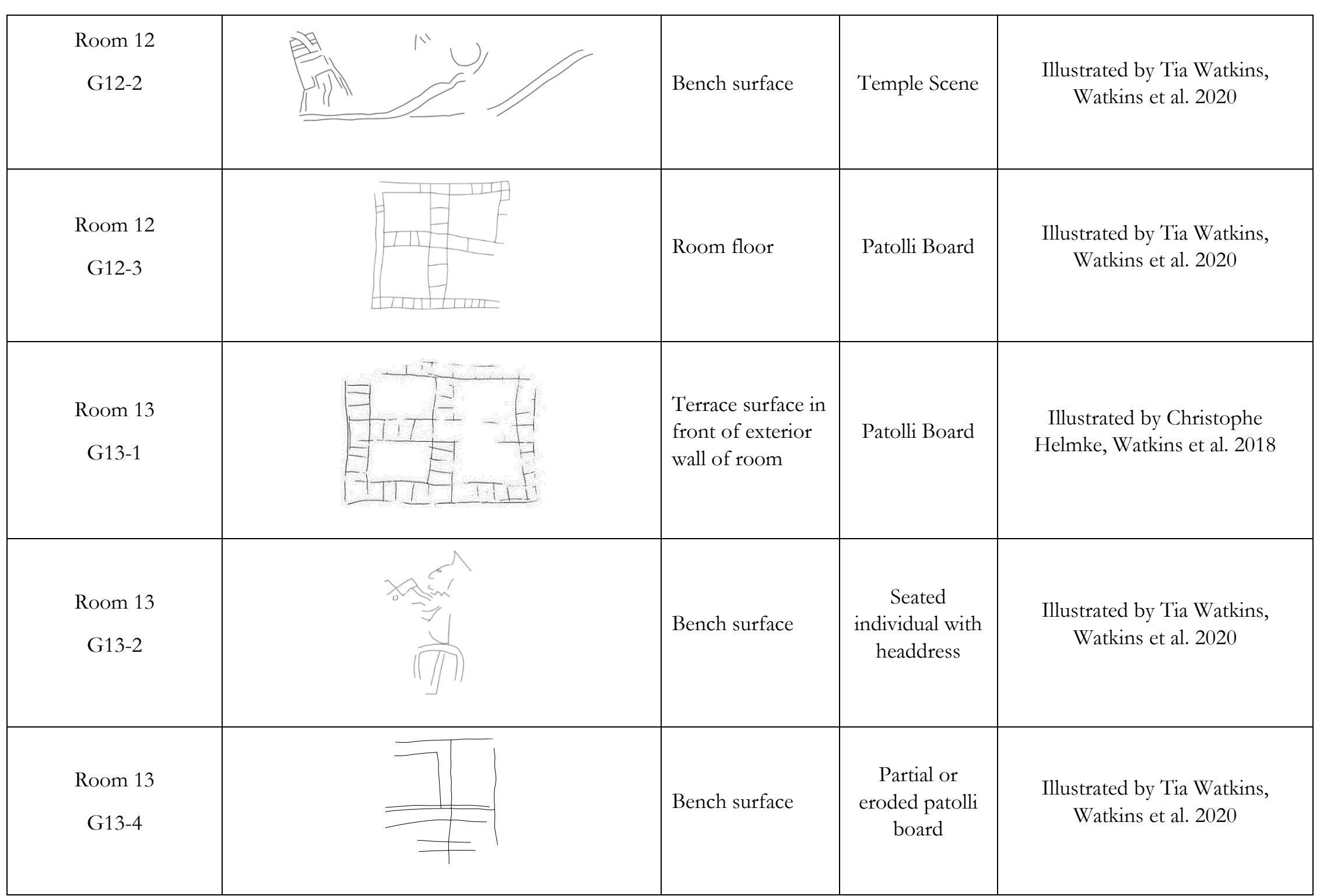




\section{REFERENCES}

Astor-Aguilera, M 2010 Maya World of Communicating Objects: Quadripartite Crosses, Trees, and Stones. Albuquerque : University of New Mexico Press.

Awe, J J 1992 Dawn in The Land Between the Rivers: Formative Occupation at Cahal Pech, Belize And Its Implications for Preclassic Occupation in The Central Maya Lowlands. University College London.

Awe, J J 2008 Architectural Manifestations of Power and Prestige: Examples from Classic Period Monumental Architecture at Cahal Pech, Xunantunich and Caracol, Belize. Research Reports in Belizean Archaeology, 5, pp.159-173.

Awe, J J, Helmke C, Slocum D and Tilden D 2020 Ally, Client or Outpost? Evaluating the Relationship between Xunantunich and Naranjo in the Late Classic Period. Ancient Mesoamerica, Special Section on "Making and Breaking Boundaries in the Maya Lowlands: Alliance and Conflict across the Guatemala-Belize Border".

Carod-Artal, F J 2015 Hallucinogenic drugs in pre-Columbian Mesoamerican Cultures. Neurología (English Edition), 30 (1), SEGO., pp.42-49.

Chuchiak, J F I 2003 'It is their drinking that hinders them': Balché and the use of ritual intoxicants among the colonial Yucatec Maya, 1550-1780. Estudios de Cultura Maya, XXIV, pp.137-171.

Cowgill, G L 2015 Ancient Teotihuacan: Early Urbanism in Central Mexico. New York: Cambridge University Press.

Durán, D [1574-1579] 1971 Book of the Gods and Rites and the Ancient Calendar, (Tr.) (Ed.) Horcasitas, F and Heyden, D Norman: University of Oklahoma Press.

Durán, D [1588] 1994 Historia de las Indias de Nueva-España y Islas de Teirra Firme. The History of the Indies of New Spain. Heyden, D (Ed.) Norman: University of Oklahoma Press.

Fitzmaurice, R E 2018. Pre-Columbian Maya Graffiti: New Insights from Xunantunich, Belize. Unpublished Masters Dissertation University College London.

Graham, E 1994 The Highlands of the Lowlands: Environment and Archaeology in Stann Creek District, Belize, Central America. Monographs in World Archaeology, 19. 
Haviland, W A and Haviland A D L 1995 Glimpses of the Supernatural: Altered States of Consciousness and the Graffiti of Tikal, Guatemala. Latin American Antiquity, 6 (4), pp.295-309.

Helmke, C, Awe J J and Grube N 2010 The Carved Monuments and Inscriptions of Xunantunich. In: LeCount, L. J. and Yaeger, J. (Eds). Classic Maya Provincial Politics: Xunantunich and Its Hinterlands. Tucson: University of Arizona Press. pp.97-121.

Hutson, S R 2011 The Art of Becoming: The Graffiti of Tikal, Guatemala. Latin American Antiquity, 22 (4), pp.403-426.

Jackson, S and Stuart D 2001 The Aj K'uhun Title. Ancient Mesoamerica, 12 (2), pp.217-228.

Kampen, M 1978 The Graffiti of Tikal, Guatemala. Estudios de Cultura Maya, 11, pp.155-180.

LeCount, L J and Yaeger J 2010 A Brief Description of Xunantunich, In LeCount, L $\mathrm{J}$ and Yaeger, J (Eds.) Classic Maya Provincial Politics: Xunantunich and its Hinterlands. Tuscon : University of Arizona Press. pp.67-78.

Lemus-Fuented, E 2006 Los enemas prehispanicos como instrumentos para aplicar probioticos. Temas de Ciencia y Tecnología 10(29): 17-20.

Lewis-Williams, J D 2002 Mind in the Cave. London: Thames and Hudson.

Lewis-Williams, J D and Dowson T A 1988 The Signs of All Times: Entoptic Phenomena in Upper Palaeolithic Art. Current Anthropology, 29 (2), pp.201-245.

Mackie, E W 1985. Excavations at Xunantunich and Pomona, Belize, in 1959-1960: a ceremonial centre and an earthen mound of the Maya Classic period. Oxford: B.A.R.

Maler, T 1901 Researches in the Central Portion of the Usumatsintla Valley, In Memoirs of the Peabody Museum, Harvard University Vol. II, No. 1. 1901. Cambridge, MA .

Maler, T 1903. Researches in the Central Portion of the Usumatsintla Valley. In: Memoirs of the Peabody Museum, Harvard University Vol. II, No. 2. 1903. Cambridge, MA .

Martin, S 2001 No Court and Realm: Architectural Signatures in The Classic Maya Southern Lowlands, In Inomata, $\mathrm{T}$ and Houston, S (Eds.) Royal Courts of The Ancient Maya, Vol 1. Colorado: Westview Press. pp.168-194. 
McCurdy, L, Brown M K, and Dixon N 2018 Tagged Walls: The Discovery of Ancient Maya Graffiti at El Castillo, Xunantunich. Research Reports in Belizean Archaeology, 15, pp.181-193.

Navarro-Castillo, M, Sheseña A, and Pincemin S 2017 The Maya Graffiti of Plan de Ayutla, Chiapas. Latin American Antiquity, 29 (2), pp.386-393.

Neff, L S 1995 Excavations of Structure A-20 on the Castillo, Xunantunich, In Leventhal, R M (Ed.) Xunantunich Archaeological Project, 1995 Field Season. Institute of Archaeology, University of California Los Angeles, and Institute of Archaeology, Belmopan, Belize. pp.38-58.

Olton, E 2015 A Sub-Rosa Narrative: Graffiti from Room 9, Structure 5D-65 in Tikal, Guatemala, In Olton, E and Lovata, T (Eds.) Understanding Graffiti: Multidisciplinary Studies from Prehistory to the Present. Walnut Creek: Left Coast Press Inc. pp.159-175.

Olton, E 2018 A New Look at Maya Graffiti from Tikal. In: Scribbling through History: Graffiti, Places and People from Antiquity to Modernity. London: Bloomsbury.

Parmington, A 2011 Space and Sculpture in The Classic Maya City. New York: Cambridge University Press.

Patrois, J 2013 Río Bec graffiti: A private form of art. Ancient Mesoamerica, 24(2), pp.433-447.

Robin, C 2012 Chan: An Ancient Maya Farming Community. Gainsville: University Press of Florida.

de Sahagún, B [1554-1590] 1959 General history of the things of New Spain: Florentine codex. Anderson, A J O and Dibble, C E (Eds.) Salt Lake City, UT: University of Utah.

Smith, L 1977 Patolli, at the Ruins of Seibal, Petén, Guatemala, In: Hammond, N (Ed.) Social Patterns in Maya Prehistory. London: Academic Press. pp.349-363.

Stark, B L and Stoner W D 2017 Watching the Game: Viewership of Architectural Mesoamerican Ball Courts. Latin American Antiquity, 28(3), pp.409-430.

Swezey, W R and Bittman B 1983 El rectángulo de cintas y el patolli: nueva evidencia de la antigüidad, distribución, variedad y formas de practicar este juego precolombino. Mesoamerica, 6, pp.373-410.

Tedlock, D 1985 Popol Vub the definitive edition of the Mayan Book of the Dawn of Life and the Glories of the Gods and Kings. Revised ed. New York: Simon and Schuster. 
Thompson, E H 1898 "Ruins of Xkichmook, Yucatan", Publications of the Field Columbian Museum, Anthropological Series, 2:3, 209-230.

Verbeeck, L 1998 Bul: A Patolli Game in Maya Lowland. Board Games Studies, 1, pp.82-100.

Walden, J P, Watkins, T B, Shaw-Muller K, Ebert, C E, Messinger, E, Guerra, R A and J.J. Awe 2020. Multiscalar Approaches to Reconstructing Classic Maya Strategies of Ceremonial Inclusion and Exclusion Through the Accessibility of Architecture at Lower Dover, Belize. British Archaeological Reports: Archaeology of The Maya.

Walden, J P and Voorhies B 2017 Ancient Maya Patolli. In Voorhies, B (Eds.) Prehistoric Games of North American Indians: Subarctic to Mesoamerica. Salt Lake City, UT: University of Utah Press. pp.197-218.

Watkins, T B, Awe J J, Helmke C, and Fitzmaurice R 2018 Classic Maya Palaces and Their Roles within the Greater Ceremonial Centre: Results from the 2017 Field Season at Xunantunich, Belize, In: Ebert, C, Hoggarth, J A and Awe, J J (Eds.) The Belize Valley Archaeological Reconnaissance Project: A Report of the 2017 Field Season. Waco, TX: Institute of Archaeology, Baylor University. pp.33-356

Watkins, T B 2019 Public Figures in Private Spaces: Patterns in The Built Environment as a Reflection of Elite Agency. University College London.

Watkins, T B, Ebert C E, Saldaña G, Can J and Awe J J 2020 Continued Investigations of Graffiti at Plaza A-III: The 2019 Excavations at Structure A13, In Ebert, C. et al. (Eds.) The Belize Valley Archaeological Reconnaissance Project A Report of the 2019 Field Season. Flagstaff, AZ: Department of Anthropology, Northern Arizona University. pp.125-136.

Webster, H T 1963 Tikal Graffiti. Expedition Magazine, 6 (1), pp.37-47.

Yaeger, J 1997 Excavations of Plaza A-III and Miscellaneous Excavation and Architectural Clearing in Group A, In Leventhal, R M (Ed.) Xunantunich Archaeological Project, 1997 Field Season. Institute of Archaeology, University of California Los Angeles, and Institute of Archaeology, Belmopan, Belize. pp.1455.

Yaeger, J 2005 Revisiting the Xunantunich Palace : The 2003 Excavations. Famsi.

Zender, M 2004 A Study of Classic Maya Priesthood. University of Calgary. 
Źrałka, J 2014 Pre-Columbian Maya Graffiti: Context, Dating and Function. Karaków: Alter.

Źrałka, J and Hermes B 2009 Los grafitos prehispánicos de los sitios Nakun y Yaxhá (Petén, Guatemala): su contexto arqueológico, iconográfico y cronológico, In Vidal C and Muñoz G (Eds.) Los grafitos mayas (Cuadernos de arquitectura y arqueologia maya 2). Valencia: Sarriópapel., pp.133-158. 